\title{
DISPERSIVE LIQUID-LIQUID MICROEXTRACTION FOR THE SIMULTANEOUS SEPARATION OF TRACE AMOUNTS OF ZINC AND CADMIUM IONS IN WATER SAMPLES PRIOR TO FLAME ATOMIC ABSORPTION SPECTROMETRY DETERMINATION
}

\author{
Sayed Zia Mohammadi, Yar Mohammad Baghelani and Fatemeh Mansori \\ Department of Chemistry, Payame Noor University, Bam, Iran \\ Tayebeh Shamspur* \\ Department of Chemistry, Shahid Bahonar University of Kerman, Kerman, Iran \\ Daryoush Afzali \\ Environment Department, Research Institute of Environmental Sciences, International Center for Science, High Technology \& \\ Environmental Sciences, Kerman, Iran
}

Recebido em 9/2/11; aceito em 11/6/11; publicado na web em 8/8/11

\begin{abstract}
In the proposed method, carbon tetrachloride and ethanol were used as extraction and dispersive solvents. Several factors that may be affected on the extraction process, such as extraction solvent, disperser solvent, the volume of extraction and disperser solvent, $\mathrm{pH}$ of the aqueous solution and extraction time were optimized. Under the optimal conditions, linearity was maintained between $1.0 \mathrm{ng}$ $\mathrm{mL}^{-1}$ to $1.5 \mu \mathrm{g} \mathrm{mL}{ }^{-1}$ for zinc and $1.0 \mathrm{ng} \mathrm{mL}^{-1}$ to $0.4 \mu \mathrm{g} \mathrm{mL}^{-1}$ for cadmium. The proposed method has been applied for determination of trace amount of zinc and cadmium in standard and water samples with satisfactory results
\end{abstract}

Keywords: dispersive liquid-liquid microextraction; cadmium determination; zinc determination.

\section{INTRODUCTION}

Importance positive and negative roles of trace heavy metal ions in human health are known. Considering biological research, the roles of some trace and ultra-trace elements in the body is very important and has diverse function. ${ }^{1-5}$ Some of trace elements are essential to life while others are toxic even at very low concentrations. Therefore, due to the importance of heavy metals at trace level in the human health and environment, the sensitive and accurate determination of the levels of heavy metals in the environmental samples have been continuously carried out on the analytical and environmental laboratories around the world. ${ }^{6}$

Several novel microextraction techniques are being developed in order to reduce the analysis step, increase the sample throughput and to improve the quality and the sensitivity of the analytical methods. The cloud point extraction (CPE), ${ }^{7}$ the homogeneous liquid-liquid extraction (HLLE), ${ }^{8} 9$ the liquid phase microextraction (LPME) $)^{10,11}$ and the solid phase microextraction (SPME) ${ }^{12,13}$ are fairly new methods of sample preparation. They are employed in the separation and preconcentration of environmental contaminants in different matrices and can solve some of the problems, encountered with the conventional pretreatment techniques. Recently, a new liquid-liquid microextraction method namely, dispersive liquid-liquid microextraction (DLLME) was proposed. ${ }^{14}$ This method has been applied for the determination of trace organic pollutants and metal ions in the environmental samples. ${ }^{15-24}$ Recently we reported a new DLLME method to preconcentration of silver and copper without the addition of the chelating agent, ${ }^{25,26}$ and a new ultra sound assisted emulsification for simultaneous microextraction trace amount of cobalt and manganese. ${ }^{27}$

DLLME is based on a ternary component solvent system like homogeneous liquid-liquid extraction and cloud point extraction. In this method, the appropriate mixture of extraction solvent and

\footnotetext{
*e-mail: shamspur@gmail.com
}

dispersive solvent is injected into an aqueous sample rapidly by a syringe, and a cloudy solution is formed. The analyte in the sample is extracted into the fine droplets of extraction solvent. After extraction, phase separation is performed by centrifugation.

The aim of this work is at combining ligandless dispersive liquidliquid microextraction (LL-DLLME) with FAAS and proposes a new method for separation, preconcentration and determination trace amounts of zinc and cadmium in water and standard samples.

\section{EXPERIMENTAL}

\section{Instrumentation}

A SensAA GBC atomic absorption spectrometer (Dandenong, Australia) equipped with deuterium background correction and airacetylene burner was used for absorbance measurements according to instrument instruction. Zinc and cadmium hollow cathode lamps were used as light source. The operating parameters of elements were set according to the manufacturer recommendation. The acetylene flow rate and the burner height were adjusted in order to obtain the maximum absorbance signal, while aspirating the analyte solution. A Metrohm 692 pH meter (Herisau, Switzerland) was used for $\mathrm{pH}$ measurements. A Centurion scientific centrifuge model 1020 D.E. (West Sussex, United Kingdom) was used to accelerate the phase separation.

\section{Reagents and solutions}

Doubly distilled de-ionized water was used throughout the experimental work. Stock solutions of zinc and cadmium were prepared by dissolving appropriate amount of ultra pure salt obtained from Merck (Darmstadt, Germany) in $2 \mathrm{~mol} \mathrm{~L}^{-1} \mathrm{HNO}_{3}$. Working standard solutions were obtained by appropriate dilution of the stock standard solution. The laboratory glassware was kept overnight in a $1.4 \mathrm{~mol}$ $\mathrm{L}^{-1} \mathrm{HNO}_{3}$ solution. Before using, all of the glassware were washed with de-ionized water and dried. A solution of $10 \% \mathrm{NaCl}$ (Merck) 
was prepared by dissolving of $10 \mathrm{~g}$ of $\mathrm{NaCl}$ in $100 \mathrm{~mL}$ of de-ionized water. The solutions of alkali metal salt $(1 \% \mathrm{w} / \mathrm{v})$ and various metal salts $(0.1 \% \mathrm{w} / \mathrm{v})$ were used to study the interference of anions and cations, respectively.

\section{Ligandless-dispersive liquid-liquid microextraction procedure}

In this study, combination of LL-DLLME with FAAS was developed for determination trace amounts of cadmium and zinc ions. It is based on microextraction of cadmium hydroxide and zinc hydroxide with using of ethanol as dispersive solvent and carbon tetrachloride as extraction solvent. All standards and samples were prepared for analysis according to the following procedure. A 8.0 $\mathrm{mL}$ aliquot of each sample was placed in a screw cap glass test tube with a conic bottom. To each test tube, $1 \mathrm{~mL}$ of $0.1 \mathrm{~mol} \mathrm{~L}^{-1}$ di potassium hydrogen phosphate $(\mathrm{pH} 10)$ and $1 \mathrm{~mL}$ of $10 \%(\mathrm{w} / \mathrm{v})$ $\mathrm{NaCl}$ were added. Then, $2.0 \mathrm{~mL}$ of ethanol containing $30.0 \mu \mathrm{L}$ of carbon tetrachloride was injected rapidly into the sample solution. In this step, zinc and cadmium reacted with hydroxide ions for $\mathrm{Zn}(\mathrm{OH})_{2}$ and $\mathrm{Cd}(\mathrm{OH})_{2}$ formation, then the aqueous, dispersive and extraction solvents were mixed and a cloudy solution was formed. After formation of cloudy solution, $\mathrm{Zn}(\mathrm{OH})_{2}$ and $\mathrm{Cd}(\mathrm{OH})_{2}$ diffuses into the extraction solvent quickly, because of the high surface area between extraction solvent and the aqueous phase. Then, the solution was centrifuged at $3000 \mathrm{rpm}$ for $5 \mathrm{~min}$, and the dispersed fine droplets of $\mathrm{CCl}_{4}$ were deposited at the bottom of conical test tube. The sediment phase was removed and $0.7 \mathrm{~mL}$ of $1.0 \mathrm{~mol} \mathrm{~L}^{-1}$ $\mathrm{HNO}_{3}$ in ethanol was added to it. The final solution was aspirated directly into the flame of AAS.

\section{Sample preparation}

Tow certified reference materials (CRMs) furnished by the National Institute for Environment Studies (NIES) No. 1 Pepperbush and NIES No. 7 Tea Leave have been analyzed. Approximately 0.40 g of NIES No. 1 and 1.0 g NIES No. 7 were weighted accurately into a Teflon cup and dissolved in concentrated nitric acid $(\sim 10 \mathrm{~mL})$ with heating on a water bath. The solution was cooled, diluted and filtered. The filtrate was made to $100.0 \mathrm{~mL}$ with de-ionized water in a calibrated flask. An aliquot of the sample solution was taken individually, and analyte ions were determined by the general procedure.

River and well water samples were collected in acid-leached polyethylene bottles. The river water samples were collected from Rayen, Shahdad and Kohpayeh in Kerman province, Iran. The well water sample was collected from Payame Noor University, Kerman, Iran. The only pretreatment was acidification to $\mathrm{pH} 2$ with nitric acid, which was performed immediately after collection, in order to prevent adsorption of the metal ions on the flask walls. The samples were filtered before analyses through a cellulose membrane of 0.45 $\mu \mathrm{m}$ pore size (Millipore).

\section{RESULTS AND DISCUSSION}

\section{Selection of disperser solvent}

The disperser solvent must be miscible in extraction solvent (organic phase) and also sample solution (aqueous phase). Therefore, acetone, methanol, ethanol and tetrahydrofuran were tested. The effect of these solvents on the extraction efficiency of LL-DLLME was investigated using $2.0 \mathrm{~mL}$ of each solvent containing $30.0 \mu \mathrm{L}$ of $\mathrm{CCl}_{4}$ as the extraction solvent. The extraction efficiency of LL-DLLME for zinc and cadmuium in acetone, methanol, ethanol and tetrahydrofuran as disperser solvents were 86.3 and $91.4 ; 95.7$ and 97.3; 98.7 and $99.2 ; 71.8$ and 64.9 , respectively. The maximum extraction efficiency of DLLME was obtained by using ethanol as a disperser solvent. Therefore, ethanol was selected for further experiments.

\section{Effect of the disperser solvent volume}

The volume of the disperser solvent is one of the important factors to be considered in DLLME. At lower volumes of the disperser, tiny droplet formation may not be effective. This phenomenon will decrease the extraction efficiency. When the volume of the dispersive solvent is an increased, two competitive processes may occur. One is the increase in the solubility of the analytes in the aqueous phase leading to diminished partition of the polar compounds into $\mathrm{CCl}_{4}$ droplets. On the contrary, an increased volume of the partitioned ethanol phase into $\mathrm{CCl}_{4}$ phase leads to increase in the extraction efficiency. Hence it was necessary to evaluate the volume effect of dispersive solvent. To obtain the optimized volume of ethanol, various experiments were performed using different volumes of ethanol (0.5-3.0 mL) containing $30.0 \mu \mathrm{L}$ of $\mathrm{CCl}_{4}$. The results are presented in Figure 1.

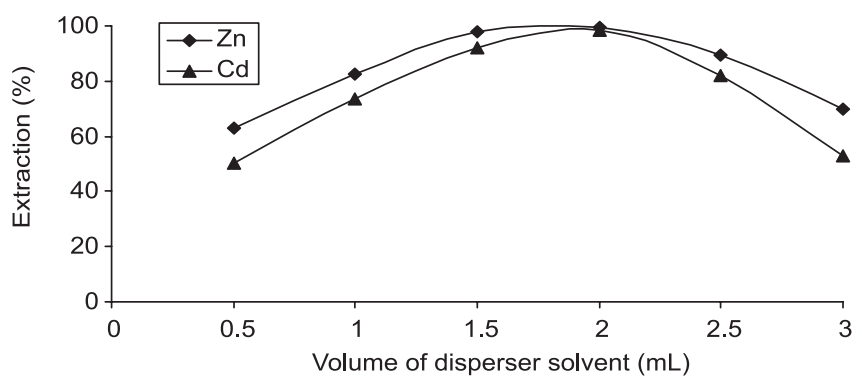

Figure 1. Effect of the disperser solvent volume (ethanol) on the LL-DLLME extraction. Conditions: $\mathrm{Zn}(\mathrm{II})$ and $\mathrm{Cd}(\mathrm{II}), 4.0$ and $0.8 \mu \mathrm{g} ; \mathrm{Buffer}, 1 \mathrm{~mL} ; \mathrm{NaCl}$ $10 \%(\mathrm{w} / \mathrm{v}), 1 \mathrm{~mL}$ and $\mathrm{CCl}_{4}, 30.0 \mu \mathrm{L}$

The results showed that the extraction efficiency increased with the increase of the volume of ethanol to $2.0 \mathrm{~mL}$. Reduction in the extraction efficiency was observed after the volume of ethanol exceeded $2.0 \mathrm{~mL}$. Finally, $2.0 \mathrm{~mL}$ ethanol was chosen as the optimum volume.

\section{Selection of the extraction solvent}

The type of extraction solvent in DLLME is an essential consideration for efficient extraction. It should be higher density than water, high extraction capability of the interested compounds and low solubility in water. 1, 2-dicholorobenzene (1, 2-DCB) and $\mathrm{CCl}_{4}$ were studied as extraction solvent. The effect of these solvents on the extraction efficiency of LL-DLLME was investigated using $2.0 \mathrm{~mL}$ of ethanol as a dispersive solvent containing $30 \mu \mathrm{L}$ of each solvent. The extraction efficiency of LL-DLLME for zinc and cadmium with 1, 2-DCB and $\mathrm{CCl}_{4}$ as extraction solvent were 75.6 and 83.0; 97.2 and 98.5 , respectively. Therefore, $\mathrm{CCl}_{4}$ was selected as extraction solvent for subsequent experiments.

\section{Effect of the organic extraction volume}

In order to examine the effect of the volume of extraction solvent, different volume of $\mathrm{CCl}_{4}(20-60 \mu \mathrm{L})$ were used as extraction solvent to the same LL-DLLME procedure. The results are shown in Figure 2.

The results showed that the extraction efficiency increased with the increase of the volume of $\mathrm{CCl}_{4}$ to $30 \mu \mathrm{L}$. Reduction in the extraction efficiency was observed after the volume of $\mathrm{CCl}_{4}$ exceeded 


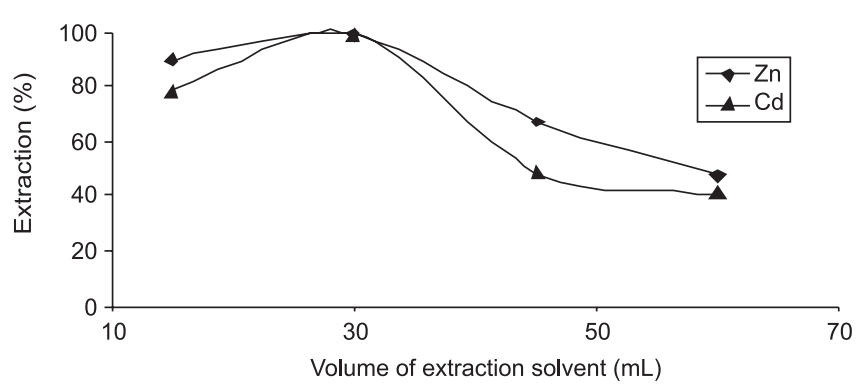

Figure 2. Effect of the extraction solvent volume $\left(\mathrm{CCl}_{4}\right)$ on the $\mathrm{LL}$-DLLME extraction. Conditions were the same as Figure 1

$30 \mu \mathrm{L}$. Finally, based on these observations, a volume of $30 \mu \mathrm{L}$ was used for further experiments.

\section{Effect of pH on LL-DLLME of ions}

The effect of $\mathrm{pH}$ on the LL-DLLME extraction of zinc and cadmium was studied in the $\mathrm{pH}$ range of 3-11. The $\mathrm{pH}$ of the metal sample solutions was adjusted by using $\mathrm{NaOH}$ or $\mathrm{HNO}_{3}$ solutions. As can be seen in Figure 3, the highest extraction efficiency of zinc and cadmium was obtained at $\mathrm{pH}$ range of 9-11. At low $\mathrm{pHs}$, the extraction efficiency don't complete. It mean that the formation of $\mathrm{Zn}(\mathrm{OH})_{2}$ and $\mathrm{Cd}(\mathrm{OH})_{2}$ in low pHs isn't completed.

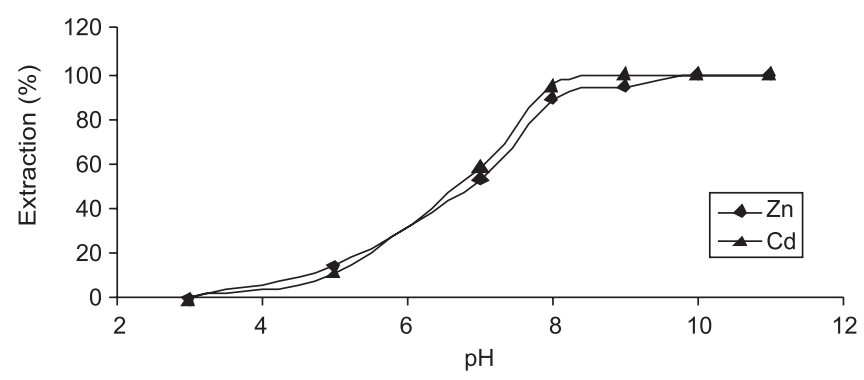

Figure 3. Effect the pH of sample solution on the LL-DLLME extraction. Conditions were the same as Figure 1

\section{Salting out effect}

In the extraction, the solubility of many analytes in aqueous solutions decreases with increasing ionic strength due to salting out effect. Sodium chloride was used to investigate the influence of ionic strength on the extraction efficiency. For investigating the influence of the ionic strength on the LL-DLLME performance, several experiments were performed by adding varying amounts of $\mathrm{NaCl}$ from 0.25 to $1.5 \mathrm{~g}$. The rest of the experimental conditions were kept constant. The extraction efficiency of LL-DLLME for zinc and cadmium with 0.25 to $1.5 \mathrm{~g}$ of $\mathrm{NaCl}$ was in the range 57.3-98.3. The resulting data were showed that the maximum extraction was obtained in the presence $1 \mathrm{~g}$ of $\mathrm{NaCl}$. Therefore, $1 \mathrm{~mL} \mathrm{NaCl}$ 10\% was used in all further experiments.

\section{Effect of the extraction time}

In DLLME, the extraction time is defined as interval time between the injection of the disperser and extraction solvents and the starting of centrifuge. The effect of extraction time was examined in the range of $10 \mathrm{~s}$ to $30 \mathrm{~min}$ with the constant experimental conditions. The obtained results showed that the extraction time was no significant influence on the signal of zinc and cadmium. Therefore, the LL-DLLME method was time-independent, which was the most important advantage of this technique.

\section{Effect of foreign ions}

In view of the high selectivity provided by flame atomic absorption spectrometry, the only interference may be attributed to the separation step. Interferences studied were those related to the separation step, cations that may react with hydroxide or species that may react with analytes and decrease the extraction efficiency. To perform this study, various salts and metal ions were added individually to a solution containing $0.5 \mu \mathrm{g} \mathrm{mL}^{-1}$ zinc and $0.1 \mu \mathrm{g} \mathrm{mL}^{-1}$ cadmium, individually and the LL-DLLME procedure was applied. The tolerance limit was set as the concentration of the diverse ion required to cause $\pm 5 \%$ error. Results are given in Table 1 . These results demonstrate that the presence of large amounts of species commonly present in water samples have no significant effect on the LL-DLLME of zinc and cadmium.

Table 1. Tolerance limit of foreign ions

\begin{tabular}{lcccc}
\hline Foreign ions & $\begin{array}{c}\text { Interference/ } \\
\mathrm{Zn}(\mathrm{II}) \text { ratio }\end{array}$ & $\begin{array}{c}\mathrm{Re} \% \text { of } \\
\mathrm{Zn}(\mathrm{II})\end{array}$ & $\begin{array}{c}\text { Interference/ } \\
\mathrm{Cd}(\mathrm{II}) \text { ratio }\end{array}$ & $\begin{array}{c}\mathrm{Re} \% \text { of } \\
\mathrm{Cd}(\mathrm{II})\end{array}$ \\
\hline $\mathrm{PO}_{4}{ }^{3-}, \mathrm{HPO}_{4}{ }^{2-}$ & 4500 & 98 & 5000 & 97 \\
$\mathrm{CH}_{3} \mathrm{COO}^{-}$ & 3000 & 95 & 3000 & 96 \\
$\mathrm{Ca}^{2+}, \mathrm{Mg}^{2+}$ & 2500 & 95 & 3000 & 97 \\
$\mathrm{Co}^{2+}$ & 300 & 105 & 300 & 96 \\
$\mathrm{Fe}^{2+}$ & 800 & 95 & 500 & 96 \\
$\mathrm{Ni}^{2+}$ & 800 & 97 & 1000 & 105 \\
$\mathrm{Al}^{3+}$ & 400 & 95 & 500 & 95 \\
$\mathrm{As}^{3+}$ & 600 & 98 & 1000 & 95 \\
$\mathrm{Fe}^{3+}$ & 200 & 96 & 250 & 95 \\
$\mathrm{Cu}^{2+}$ & 150 & 96 & 100 & 105 \\
$\mathrm{Mn}^{2+}$ & 800 & 97 & 800 & 95 \\
\hline $\mathrm{Con}^{2+}$ & & & &
\end{tabular}

Conditions were the same as Figure 1.

\section{Calibration, precision and detection limit}

Under the optimized conditions, calibration curves were constructed for the determination of zinc and cadmium according to the LL-DLLME procedure. Linearity was maintained between 1.0 $\mathrm{ng} \mathrm{mL} \mathrm{L}^{-1}$ to $1.5 \mu \mathrm{g} \mathrm{mL}^{-1}$ for zinc and $1.0 \mathrm{ng} \mathrm{mL}^{-1}$ to $0.4 \mu \mathrm{g} \mathrm{mL}^{-1}$ for cadmium. The equations for the lines were $A=0.6361 C+0.0051$ $(R=0.999)$ and $A=2.4297 C+0.0040(R=0.999)$, respectively. In these equations, $A$ is the absorbance value of the eluent, $C$ is concentration of zinc and cadmium $\left(\mu \mathrm{g} \mathrm{mL}^{-1}\right)$ and $\mathrm{R}$ is correlation coefficients. Seven replicate determination of a mixture of $0.5 \mu \mathrm{g}$ $\mathrm{mL}^{-1}$ zinc and $0.1 \mu \mathrm{g} \mathrm{mL}^{-1} \mathrm{cadmium}$ in original solution gave a mean absorbance of 0.311 and 0.243 with relative standard deviation 1.5 and $1.7 \%$, respectively. The detection limits based on $3 \mathrm{~S}_{\mathrm{b}} / \mathrm{m}$ for zinc and cadmium in the original solution were 0.3 and $0.4 \mathrm{ng}$ $\mathrm{mL}^{-1}$, respectively. The limit of quantification based on $10 \mathrm{~S}_{\mathrm{b}}$ for zinc and cadmium in the original solution was 1.0 and $1.3 \mathrm{ng} \mathrm{mL}$ ${ }^{1}$, respectively. Enrichment factors were calculated as the ratio of the slope of calibration curve after and before of microextraction. The enrichment factors for zinc and cadmium were 10.3 and 13.4, respectively.

\section{Accuracy of the method}

The accuracy and applicability of the proposed method has been applied to the determination of $\mathrm{Zn}$ (II) and $\mathrm{Cd}$ (II) ions in National Institute for Environment Studies (NIES) No. 1 pepperbush and NIES No. 7 Tea Leaves. Results are given in Table 2. It was found that there is no significant difference between results obtained by the proposed method and the certified results. These results indicate the 
Table 2. Determination of zinc and cadmium in biological samples

\begin{tabular}{lcc}
\hline Sample & Certified value $\left(\mu \mathrm{g} \mathrm{g}^{-1}\right)$ & Found $^{\mathrm{a}}\left(\mu \mathrm{g} \mathrm{g}{ }^{-1}\right)$ \\
\hline NIES, No. 1 & $\mathrm{Zn:} 340 \pm 20$ & $\mathrm{Zn}: 346.9 \pm 14.1$ \\
Pepperbush & Cd: $6.7 \pm 0.5$ & $\mathrm{Cd}: 6.8 \pm 0.3$ \\
NIES, No. 7 & Zn: 33 & Zn: $33.7 \pm 1.4$ \\
Tea Leaves & Cd: 0.030 & $\mathrm{Cd}: 0.029 \pm 0.002$ \\
\hline
\end{tabular}

aMean \pm standard deviation $(n=4)$

applicability of the developed LL-DLLME procedure for zinc and cadmium determination is free of interference.

\section{Analysis of water samples}

The LL-DLLME procedure has been applied to the determination of zinc and cadmium content in different water samples. The results are given in Table 3 .

The recovery of zinc and cadmium from water samples spiked with $\mathrm{Zn}$ (II) and $\mathrm{Cd}(\mathrm{II})$ were also studied. The results are given in Table 3. According this Table, the added $\mathrm{Zn}$ (II) and $\mathrm{Cd}$ (II) ions can be quantitatively recovered from the water samples by the LL-DLLME procedure.

These results demonstrate the applicability of the procedure for zinc and cadmium determination in water samples. The recovery of zinc and cadmium added to the samples demonstrates the efficiency of the proposed method.

\section{CONCLUSIONS}

This work has been demonstrated combination of LL-DLLME with flame atomic absorption spectrometry provides a novel route for trace determination of zinc and cadmium in water samples. The main benefits of the LL-DLLME methodology were: minimum use of toxic organic solvent, simplicity, low cost, enhancement of sensitivity, and rapid analysis time.

A comparison of the present method with the other reported preconcentration methods ${ }^{28-33}$ for the cadmium and zinc extraction from water samples was given in Table 4 . The obtained detection limits by the proposed procedure is less than some the other methods. ${ }^{28,30-33}$ Also, the enrichment factors are higher than the CPE techniques ${ }^{28,32}$ and the RSD\% is less than some the other methods. ${ }^{28,30,31,33}$ Finally, the necessary sample volume is lower than the other methods. ${ }^{28-33}$

Table 3. Determination of zinc and cadmium in water samples

\begin{tabular}{|c|c|c|c|c|}
\hline Sample & $\begin{array}{l}\text { Found }^{\mathrm{a}} \\
\left(\mathrm{ng} \mathrm{mL} \mathrm{mL}^{-1}\right)\end{array}$ & $\begin{array}{l}\text { Added } \\
\left(\mathrm{ng} \mathrm{mL} L^{-1}\right)\end{array}$ & $\begin{array}{l}\text { Found } \\
\left(\mathrm{ng} \mathrm{mL}^{-1}\right)\end{array}$ & Recovery (\%) \\
\hline $\begin{array}{l}\text { River Water } \\
\text { (Rayen, Kerman) }\end{array}$ & $\begin{array}{c}\mathrm{Zn}: 22.4 \pm 0.6 \\
\mathrm{Cd}: 1.13 \pm 0.04\end{array}$ & $\begin{array}{l}\mathrm{Zn}: 20.0 \\
\mathrm{Cd}: 5.00\end{array}$ & $\begin{array}{l}\mathrm{Zn}: 43.1 \\
\mathrm{Cd}: 6.18\end{array}$ & $\begin{array}{c}103.5 \\
101\end{array}$ \\
\hline $\begin{array}{l}\text { Well Water (Payame Noor } \\
\text { University of Kerman) }\end{array}$ & $\begin{array}{l}\mathrm{Zn}: 29.2 \pm 1.1 \\
\mathrm{Cd}: 2.28 \pm 0.09\end{array}$ & $\begin{array}{l}\mathrm{Zn}: 20.0 \\
\mathrm{Cd}: 5.00\end{array}$ & $\begin{array}{l}\mathrm{Zn}: 49.6 \\
\mathrm{Cd}: 7.31\end{array}$ & $\begin{array}{c}102 \\
100.6\end{array}$ \\
\hline $\begin{array}{l}\text { River Water } \\
\text { (Shahdad, Kerman) }\end{array}$ & $\begin{array}{c}\mathrm{Zn}: 25.8 \pm 0.7 \\
\mathrm{Cd}: 1.23 \pm 0.06\end{array}$ & $\begin{array}{l}\mathrm{Zn}: 20.0 \\
\mathrm{Cd}: 5.00\end{array}$ & $\begin{array}{l}\mathrm{Zn}: 45.5 \\
\mathrm{Cd}: 6.20\end{array}$ & $\begin{array}{l}98.5 \\
99.4\end{array}$ \\
\hline $\begin{array}{l}\text { River Water } \\
\text { (Kohpayeh, Kerman) }\end{array}$ & $\begin{array}{l}\mathrm{Zn}: 24.5 \pm 0.7 \\
\mathrm{Cd}: 1.18 \pm 0.05\end{array}$ & $\begin{array}{l}\mathrm{Zn}: 20.0 \\
\mathrm{Cd}: 5.00\end{array}$ & $\begin{array}{l}\mathrm{Zn}: 44.6 \\
\mathrm{Cd}: 6.15\end{array}$ & $\begin{array}{c}100.5 \\
99.4\end{array}$ \\
\hline
\end{tabular}

average of four determination \pm standard deviation

Table 4. Comparison of the proposed method with other reported methods for preconcentration of silver

\begin{tabular}{|c|c|c|c|c|c|c|c|}
\hline System & Element & Analysis method & Sample volume (mL) & Enrichment factor & $\operatorname{RSD}(\%)$ & $\begin{array}{c}\text { LOD } \\
\left(\mathrm{ng} \mathrm{mL}^{-1}\right)\end{array}$ & Ref. \\
\hline CPE & $\begin{array}{l}\mathrm{Zn} \\
\mathrm{Cd}\end{array}$ & ICP-OES & 15 & $\begin{array}{c}9.4 \\
10.1\end{array}$ & $\begin{array}{l}1.3 \\
2.6\end{array}$ & $\begin{array}{l}1.1 \\
6.3\end{array}$ & 28 \\
\hline CPE & $\begin{array}{l}\mathrm{Zn} \\
\mathrm{Cd}\end{array}$ & FAAS & 50 & $\begin{array}{l}63.7 \\
57.7\end{array}$ & - & $\begin{array}{l}0.095 \\
0.099\end{array}$ & 29 \\
\hline CPE & $\mathrm{Zn}$ & Spectrophotometry & 25 & - & 2.1 & 1.2 & 30 \\
\hline $\mathrm{CPE}$ & $\mathrm{Cd}$ & FAAS & 15 & 20.3 & 3.2 & 0.75 & 31 \\
\hline LL-CPE & $\mathrm{Cd}$ & FAAS & 25 & 10 & 1.6 & 1.7 & 32 \\
\hline LL-CPE & $\mathrm{Cd}$ & FAAS & 10 & 11.1 & $<3$ & 1.0 & 33 \\
\hline LL-DLLME & $\begin{array}{l}\mathrm{Zn} \\
\mathrm{Cd}\end{array}$ & FAAS & 8 & $\begin{array}{l}10.3 \\
13.4\end{array}$ & $\begin{array}{l}1.5 \\
1.7\end{array}$ & $\begin{array}{l}0.3 \\
0.4\end{array}$ & Present work \\
\hline
\end{tabular}

\section{REFERENCES}

1. Tuzen, M.; Microchem. J. 2003, 74, 289.

2. Nardi, E. P.; Evangelhista, F. S.; Tormen, L.; Saint Pierre, T. D.; Curtius, A. J.; de Souza, S. S. J.; Barbosa, F.; Food Chem. 2009, 112, 727.

3. Elci, L.; Tuzen, M.; Soylak, M. J. Hazard. Mater. 2008, 160, 462.

4. Arce, S.; Cerutti, S.; Olsina, R.; Gomez, M. R.; Martinez, L. D.; J. AOAC Int. 2008, 91, 853.

5. Kazi, T. G.; Jalbani, N.; Jamali, M. K.; Arain, M. B.; Afridi, H. I.; Kandhro, A.; Pirzado, Z.; Renal Failure 2008, 30, 737.
6. Tuzen, M.; Melek, E.; Soylak, M.; J. Hazard. Mater. 2008, 159, 335.

7. Maranhao, T. A.; Borges, D. L. G.; da Veigab, M. S.; Curtius, A. J.; Spectrochim. Acta, Part B 2005, 60, 667.

8. Ebrahimzadeh, H.; Yamini, Y.; Kamare, F.; Shariati, S.; Anal. Chim. Acta 2007, 549, 93

9. Ghiasvand, A. R.; Shadabi, S.; Mohagheghzadeh, E.; Hashemi, P.; Talanta 2005, 66, 912.

10. Ahmadi, F.; Assadi, Y.; Milani Hosseini, M. R.; Rezaee, M.; J. Chromatogr., A 2006, 1101, 307. 
11. Khalili Zanjani, M. R.; Yamini, Y.; Shariati, S.; Jonsson, J. A.; Anal. Chim. Acta 2007, 585, 286.

12. Djozan, D.; Assadi, Y.; Hosseinzadeh Haddadi, S.; Anal. Chem. 2001, 73,4054 .

13. Djozan, D.; Assadi, Y.; Chromatographia 2004, 60, 313.

14. Rezaee, M.; Assadi, Y.; Millani Hosseini, M. R.; Aghaee, E.; Ahmadi, F.; Berijani, S.; J. Chromatogr., A 2006, 1116, 1.

15. Fatahi, N.; Samadi, S.; Assadi, Y.; Milani Hosseini, M. R.; J. Cromatogr., A 2007, 1169, 63 .

16. Rezaei, F.; Bidari, A.; Pajand Birjandi, A.; Milani Hosseini, M. R.; Assadi, Y.; J. Hazard. Mater. 2008, 158, 621.

17. Zeini Jahromi, E.; Bidari, A.; Assadi, Y.; Milani Hosseini, M. R.; Jamali, M. R.; Anal. Chim. Acta 2007, 585, 305.

18. Naseri, M. T.; Milani Hosseini, M. R.; Assadi, Y.; Kiani, A.; Talanta 2008, 75, 56 .

19. Liang, P.; Sang, H.; Anal. Biochem. 2008, 380, 21.

20. Bidari, A.; Zeini Jahromi, E.; Assadi, Y.; Milani Hosseini, M. R.; Microchem. J. 2007, 87, 6.

21. Liang, P.; Peng, L.; Yan, P.; Microchim. Acta 2009, 166, 47.

22. Zang, X.; Wang, J.; Wang, O.; Wang, M.; Ma, J.; Xi, G.; Wang, Z.; Anal. Bioanal. Chem. 2008, 392, 749.
23. Chen, H.; Ying, J.; Chen, H.; Huang, J.; Liao, L.; Chromatographia 2008, 68, 629.

24. Farhadi, K.; Farajzadeh, M. A.; Matin, A. A.; Hashemi, P.; Cent. Eur. J. Chem. 2009, 7, 369.

25. Mohammadi, S. Z.; Afzali, D.; Taher, M. A.; Baghelani, Y. M.; Talanta 2009, 80, 875 .

26. Mohammadi, S. Z.; Afzali, D.; Baghelani, Y. M.; Anal. Chim. Acta 2009, 653, 173.

27. Mohammadi, S. Z.; Afzali, D.; Baghelani Y. M.; Karimzadeh, L.; J. Braz. Chem. Soc. 2011, 22, 104.

28. Silva, E. L.; Roldan, P. S.; Gine, M. F.; J. Hazard. Mater. 2009, 171, 1133.

29. Chen, J.; Teo, K. C.; Anal. Chim. Acta 2001, 450, 215.

30. Tabrizi, A. B.; Food Chem. 2007, 100, 1698.

31. Silva, E. L.; Roldan, P. S.; J. Hazard. Mater. 2009, 161, 142.

32. Candir, S.; Narin, I.; Soylak, M.; Talanta 2008, 77, 289.

33. Afkhami, A.; Madrakian, T.; Siampour, H.; J. Hazard. Mater. 2006, 138, 269. 